IZA DP No. 6021

Talking about the Pigou Paradox:

Socio-Educational Background and Educational Outcomes of AlmaLaurea

Floro Ernesto Caroleo

Francesco Pastore

October 2011 


\title{
Talking about the Pigou Paradox: Socio-Educational Background and Educational Outcomes of AlmaLaurea
}

\author{
Floro Ernesto Caroleo \\ University of Naples Parthenope \\ and IZA
}

Francesco Pastore

Seconda Università di Napoli

and IZA

Discussion Paper No. 6021

October 2011

IZA

P.O. Box 7240

53072 Bonn

Germany

Phone: +49-228-3894-0

Fax: +49-228-3894-180

E-mail: iza@iza.org

Any opinions expressed here are those of the author(s) and not those of IZA. Research published in this series may include views on policy, but the institute itself takes no institutional policy positions.

The Institute for the Study of Labor (IZA) in Bonn is a local and virtual international research center and a place of communication between science, politics and business. IZA is an independent nonprofit organization supported by Deutsche Post Foundation. The center is associated with the University of Bonn and offers a stimulating research environment through its international network, workshops and conferences, data service, project support, research visits and doctoral program. IZA engages in (i) original and internationally competitive research in all fields of labor economics, (ii) development of policy concepts, and (iii) dissemination of research results and concepts to the interested public.

IZA Discussion Papers often represent preliminary work and are circulated to encourage discussion. Citation of such a paper should account for its provisional character. A revised version may be available directly from the author. 


\section{ABSTRACT \\ Talking about the Pigou Paradox: Socio-Educational Background and Educational Outcomes of AlmaLaurea}

Italy has an immobile social structure. At the heart of this immobility is the educational system, with its high direct, but especially indirect cost, due to the extremely long time necessary to get a degree and to complete the subsequent school-to-work transition. Such cost prevents the educational system from reallocating the best opportunities to all talented young people and from altering the "typical" market mechanism of intergenerational transfer of human capital and social status. About ten years after the Bologna declaration and the " $3+2$ " reform of the university system, AlmaLaurea data relative to 2008 shows a framework not much different from that of 2000. This is apparent by looking at the socio-educational background of university graduates. Parents' educational level seems to be the main determinant of the probability to get a university degree and to get it with the highest possible grade. As previous studies have also shown, the effect of the socio-educational background on children success at the university is not direct, but through the high school track. In fact, although any secondary high school gives access to the university, nonetheless lyceums provide students with far higher quality of education than technical and professional schools.

JEL Classification: H52, I23, I24, J13, J24

Keywords: intergenerational transfers, human capital, social status, Bologna declaration, "3+2" university reform, AlmaLaurea, Italy

Corresponding author:

Francesco Pastore

Seconda Università di Napoli

Faculty of Law

Via Mazzocchi, 5

81055 - Santa Maria Capua Vetere (CE)

Italy

E-mail: francesco.pastore@unina2.it

\footnotetext{
* We are grateful to Andrea Cammelli, Angelo Di Francia and Gian Piero Mignoli for providing us with estimates based on AlmaLaurea data. A previous version of this paper has been presented at one of the AlmaLaurea Conferences (Padova, $27^{\text {th }}$ May 2009). We thank all participants. We also thank two referees for valuable comments on an earlier version of the paper. This notwithstanding, the authors are solely responsible for the opinions expressed.
} 


\section{Introduction}

Removing the conditions that lead to what is sometimes called the Pigou paradox ${ }^{1}$ is one of the aims of the Italian Constitution. Indeed, making the distribution of human capital normal like that of talents supposedly is, rather than sharply skewed like the distribution of incomes and wealth, is one of the main aims of any state funded educational system. Art. 34 of the Italian Constitution commits the educational system to the endeavor of providing freedom of access to all: "Talented and deserving young people, although without means, have the right to achieve the most they can” and such right must be granted "through scholarships, family allowances and other aid grants that should be assigned through public competitions”"2.

One of the acknowledged aims of the 1999 Bologna declaration was that of removing the obstacles that hinder the ability of all to "access study and training opportunities and related services”. The 2001 “ $3+2$ ” reform pointed to the two-tier system of education as the key tool to achieve greater education attainment and equality of access to tertiary education. A two-year specialist master program following a three-year general undergraduate cycle was, in principle, expected to reduce the (direct, but above all indirect) cost of education by reducing the length of time needed to achieve a basic qualification to access the labor market. Assessing the extent to which this has happened should be considered an integral part of the reform process and should provide, therefore, useful indications to the policy maker as to how to improve what has already been done.

A possible way to assess whether the educational system is able to remove the factors that cause the Pigou paradox consists of comparing the educational level of parents and their offspring. The stronger is the intergenerational transfer of education and, therefore, the greater is the correlation of educational levels across generations, the lesser is the ability of the educational system to reach its intend.

In fact, this paper studies the educational level and social status of parents of Italian graduates using the AlmaLaurea data bank relative to 2008. Indirectly, this exercise attempts to assess the extent to which tertiary education is able to provide equal opportunities to the potential audience of students independent of their socio-educational background.

\footnotetext{
${ }^{1}$ For a long time labor economists have been discussing possible answers to the following puzzle that Pigou termed a paradox: "How can one reconcile the normal distribution of abilities with a sharply skewed distribution of incomes?” (cit. in Mincer, 1958, p. 282).

${ }^{2}$ Our free translation in English of the Italian constitution.
} 
This enquiry proposes an interpretative frame featured by light and shade. In particular, the 2001 reform does not seem to have been able to reduce the high degree of correlation between educational levels of fathers and children, suggesting that in the years to come the Italian society will continue to experience the current high degree of social immobility. This result is partly the consequence of a lack of perspective of the reform, namely that of believing that it was possible to change the process of intergenerational transfer of social status by changing the educational system only, without modifying the constraints that affect the market for goods, credit and different types of high skill labor markets. Second, as several observers have authoritatively claimed (see, for instance, AlmaLaurea, 2008), many did not well-stomach the reform and have succeeded on neutralizing it, thanks to insufficient coordination from the Ministry of Education as to how to interpret the changes.

The rest of this paper is organized as follows. Section one motivates the paper by stressing the main peculiarities of the country's educational system and placing the analysis in the context of the existing literature on Italy. It also underlines the context of economic policy within which the reform of the university system was born, stressing in particular the declared aim of increasing social mobility. Using Eurostat and OECD data, section two studies the distribution of Italian educational levels in a comparative perspective, highlighting the gap with respect to other similar countries. Section three starts the analysis of the profile of AlmaLaurea graduates in 2008, focusing on the composition by social class and educational level of the parents of graduates in different types of degree. Section four studies the correlation between social background and university performance, measured using such indicators as the final grade at high secondary school, the final grade and the actual time used to get a university degree. Some concluding remarks follow.

\section{Motivation and the state of the art}

One of the challenges of liberal societies and a mission (granted by the Italian constitution) of any state-funded educational system consists of reducing the role of intergenerational transfers by allowing - to use the pigouvian expression - the income distribution to mirror that of talents, rather than that of income and wealth. The aim of this paper is to document the extent to which this is the case of Italy by using AlmaLaurea data.

The case of Italy is particularly interesting for two related reasons. First, as Checchi (2003) has already noted, Italy has one of the lowest levels of tertiary education attainment of all industrialized 
societies. Next section will provide up-to-date detailed evidence to show that this is the case still today.

Second, there is very low social mobility and, instead, impressive intergenerational transfer of human capital and social status. The extent of the intergenerational transfer can be better appreciated if looked at in international perspective. In their study on 42 countries of all continents, Hertz et al. (2007) show that Europe is highly heterogeneous. North-European countries exhibit the greatest degree of social mobility. Continental European countries are in the middle, not far from the USA. Italy has one of the lowest degrees of social mobility, only slightly higher than that of Latin American countries, among the most immobile societies in the sample. It means that Italy has a lower degree of educational mobility not only than European countries, where university fees are very low, but also the United States, where they are the highest.

These two stylized facts - lowest education attainment and lowest social mobility - are closely related to each other, because, as Bratti, Checchi and De Blasio (2008, p. 54) note, the new graduates are bound to be the offspring of less privileged families, thus increasing equality of opportunities almost by definition, although different policies to expand education may induce a different impact on equality of opportunities.

The evidence points to the existence of demand and supply side constraints in the market for human capital. One of the aims of the European Employment Strategy and the so-called Lisbon process was in fact removing such constraints. Within this policy approach, to ease access to tertiary education for the greatest number, therefore reducing also the degree of social inequality, the educational system should be: a) flexible so as to smooth transitions from one track / school / university to another; b) homogeneous across EU countries so as to favor international labor mobility; c) efficient so as to allow students to achieve the highest possible quality of education in the shortest possible time; d) labor market oriented; e) dual, which implies providing training together (rather than after) general education as Germany does; f) equipped to supply life-long learning.

The Bologna declaration suggested that the "3+2" educational system, involving a two-year master specialist program after a three-year general undergraduate cycle, was an important step forward towards achieving the above objectives, in the mid-term, and increasing education and social mobility, in the long-term.

The ministerial decree n. 509 awarded on the $3^{\text {rd }}$ of November 1999 on: "Norms on the teaching autonomy of universities” ruled the university reform. The traditional 4-year and 5-year programs have been maintained only for few degrees, such as Medicine and Dentistry, Pharmacy, 
Architecture and Engineering, which give access to liberal professions. In this case, there is a single program called laurea specialistica a ciclo unico. For the degree in Law, the traditional 4-year program has been transformed, first, into a 3+2 program until 2004 and, then, into a 5-year program (laurea magistrale) from the academic year 2005-6. For most types of degrees, a 3-year program (laurea triennale) has been introduced in substitution of the traditional 4-year program. A 2-year program of further studies has been introduced to complete the specialist degree (laurea specialistica).

The reform has also introduced the system of university credits. Each credit corresponds to 25 working hours: every year requires students to achieve 60 university credits. The system of university credits should allow students to move more easily from one course of study to another.

About ten years after the Bologna declaration and the ensuing university reforms it is vital to assess the results achieved in terms of educational level and inequality. The focus of this paper is on the socio-economic and educational background of graduates.

Intergenerational transfers of human capital are the main channel through which parents transfer their social status to their children. A large empirical literature explains how households affect the choices and performance of their sons, namely the probability of dropping out of school (see, for instance, O’Higgins et al., 2007), their school tracking - choice of the initial educational track and types of secondary school (Dustman, 2004; Cappellari, 2004; Brunello and Checchi, 2007; Checchi and Flabbi, 2007) - and, indirectly, their success at the university (see, among others, Cappellari, 2004; Blanden and Gregg, 2004; Bratti, Checchi and de Blasio, 2008; Checchi, Fiorio and Leonardi, 2008; Cammelli and Gasperoni, 2008), and in life - in terms of health, happiness and incomes ${ }^{3}$.

In the case of Italy, the literature invariably points to strong intergenerational persistence in educational achievement. Checchi, Ichino and Rustichini (1999) are perhaps the first to note the Italian paradox of a public educational system, almost entirely financed by the government through taxation, and designed in such a way to reduce income inequality and make intergenerational mobility easier, but returning together with a higher income inequality, also a greater level of educational inequality and intergenerational transfer than the USA. Nonetheless, in the latter country, high university fees and rigid selection mechanisms introduce several factors of selection based on talent and on family income, while scholarships and less binding credit constraints for

\footnotetext{
${ }^{3}$ Recent, comprehensive and enlightening surveys of the relevant literature include: Checchi (2006), Lochner (2008), Bjorklund and Salvanes (2010), Black and Devereux (2010).
} 
students are expected to pursue the objective of equality. The authors point to factors that discourage investment in education by poor families.

Brunello and Checchi (2007) focus on the role of school tracking in preventing greater intergenerational educational and social mobility in a number of OECD countries, including Italy. By school tracking they mean, in the case of European countries, the early choice of a given educational track, namely vocational / technical / professional school, on the one hand, and lyceum, on the other hand. They argue that, in principle, school tracking might not necessarily cause social immobility, but empirical analysis suggests that such is the overall effect.

In fact, a large literature has proven that academic performance is strongly affected by school tracking in Italy. Cappellari (2004), for instance, find that the type of high school attended greatly depends upon the family of origin and prior school performance. General high schools are found to increase the probability of transition to university and to improve performance once at university. On the other hand, private high schools appear to be associated with lower academic performance. Technical schools improve the quality of the school-to-work transition, both in terms of participation and employment probabilities.

Checchi and Flabbi (2007) compare Germany and Italy to explain another apparently paradoxical finding relative to the Italian educational system. In Germany, early tracking at the age of 10 determines whether the individual will go to the apprenticeship system or to gymnasium, which only gives access to the university. In Italy, tracking happens like in other countries at the age of 14 , at the end of low secondary school, when teenagers choose between vocational school and gymnasium. In addition, to make the system apparently more flexible, any of these secondary high school diplomas gives access to the university, provided that it lasts five years. In principle, one would expects that in Germany more than in Italy the role of family background (educational and income level of parents, books at home), is greater than that of ability, as measured by test scores, grade repetition and previous marks, considering early tracking. Instead, the authors find that the opposite holds true, with the role of family background being more important in Italy, probably because parents are free to choose the school track, independent of any indicator of performance at school; in Germany, this is not allowed.

Cappellari and Lucifora (2009) argue that the Bologna process did not change much the inequality bias of the Italian system. After the reform, individuals leaving school have had a probability of enrollment $15 \%$ higher than that of otherwise identical individuals. This increase is concentrated among individuals with good school performance and low parental background. The authors interpret this result as an indication of the existence of constraints - for good students from 
less advantaged households - on the optimal schooling decision. They also find a small negative impact of the reform on university drop-out.

Pastore (2009) point to the extremely high indirect cost of education, due to several extracurricular years to get a university degree and the very long school-to-work transition of graduates, as important factors to explain low educational attainment among the weakest social groups.

\section{Italian educational levels in a comparative perspective}

The level of investment in human capital of young people in Italy is neither among the highest in the world nor in the EU (Eurostat, 2009b). Eurostat (2009a) has recently provided statistical evidence that suggests that Italy occupies one of the lowest ranks in the EU27 in terms of the number of young people holding a university degree. In 2007, only 19 out of 100 Italians aged 2534 years have attained tertiary education. This figure has dramatically increased in the last decade and, nevertheless, this is not sufficient to change the position of the country in the EU rankings, due to the higher growth rate of other countries. The EU average is about 30 per cent, with countries like France, Spain, Denmark, Sweden and the United Kingdom reaching about 40 per cent. Only the Czech Republic, Romania and Slovenia do worse than Italy. Men strongly influence this result. In Italy only less than 15 young men, against 23 young women, out of 100 aged 25-34 years got a degree.

Nonetheless, according to the OECD (2010, Chart A2.2), the share of young people with a high school diploma that allows access to the University is in Italy around 75\%, one of the highest among OECD countries. The EU average equals 62\%. This depends on the fact that almost every other high school diploma allows access to the university. How to explain then the low share of people holding a university degree? Young people wishing to access the university experience the first problems already at the time of registration. In fact, only 51\% of the overall number of high school graduates, register (OECD, 2010, A2.4). The EU average equals 56\%. While the share of high school graduates holding the right to access tertiary education is one of the highest, that of those who actually register is one of the lowest.

In addition, a large number of candidates are creamed off during their university path. Implicit in the low share of graduates is the high share of university drop outs. Italy is the first OECD country in this special ranking: the proportion of students who entered a tertiary program and leaved without at least a first tertiary degree in 2005 was 55\% when the OECD average was 31\% (OECD, 2009, Chart A4.1). 
Summing up, out of 100 young people that obtain a high school diploma only less than 33\% obtains a degree in 2008. This share is much higher in the case of women (slightly less than 40\%) than in the case of men (26.7\%) (Chart A3.1). The graduation rate has been also decreasing after 2005 when the rate was $41 \%$. On the contrary the graduation rate in the EU has been growing from 35\% to 38\% (OECD, 2010, Chart A3.2).

What is the reason of this high rate of drop out? It is interesting to note that the United States occupy the next position in the OECD ranking of countries by university drop out. In the case of the US, the obvious explanation of the high dropout rate is the high degree of selectivity of the system as based on performance and also on university fees, one of the highest in the world. This suggests in turn that also in Italy the cost of tertiary education is higher than elsewhere. However, it is not the direct cost of university that is highest in Italy. In fact, university fees are rather low. And so is also the cost of textbooks, the expenditure for transportation as well as of room and board, considering that most students register at their home town university. It suggests that it is the indirect cost that students perceive as unbearable. The indirect cost is especially high due to the longest time necessary to obtain a degree, much higher than the 4-5 curricular years, and to complete the schoolto-work transition ${ }^{4}$. Obviously, also the direct cost of tertiary education increases with the time needed to obtain the degree.

This research adds that individuals with a different socio-educational background might perceive in a different way the high indirect cost of tertiary education. Obviously, especially young people with a low socio-educational background experience the cost of tertiary education.

Also the returns to education are rather low, as several studies show (see, for a survey, Brunello, Comi e Lucifora, 1999; 2000). The reason could be the low demand for human capital typical of Italian firms, which specialize in traditional low skill intensive manufacturing sectors.

Eurostat provides evidence on another typical feature of the process of human capital formation in Italy: the probability to attain the highest educational levels is still strongly linked to the family' socio-economic conditions. Table 1 shows, in fact, that young people belonging to households featured by a lower than average educational level have much lower probability to attain a university degree than those who belong to households where one or two parents have a degree. In fact, only 9 out of 100 people aged 25-34 years old that belong to households "with a low level of education" graduated in Italy: this figure is comparable to that of Latvia and Poland. The share

\footnotetext{
${ }^{4}$ On average it may take from 7 to 9 years to get a university degree. According to AlmaLaurea, the average duration of time needed to achieve a degree for pre-reform graduates was 7.9 in 2005 . In 2001, before the reform was implemented, the average age at graduation was 28 years.
} 
increases to $60 \%$ if one considers graduates whose parents hold a university degree. Essentially, in Italy, the offspring of better educated parents have a probability seven times higher to get a degree than their coeval living in poorer socio-economic contexts. In the United Kingdom, the comparable figure is only two. The gap increases by two and a half times in the case of France and Spain.

\section{[Table 1 about here]}

\section{AlmaLaurea data}

The following analysis is based on AlmaLaurea data. AlmaLaurea is a consortium involving an increasing number of universities. Established at the University of Bologna in 1994, in 2010 it involved 62 Italian Universities, covering $77 \%$ of all graduates.

Information is collected in two steps. First, at the time of graduation, students are requested to answer a questionnaire regarding their socio-educational background and their educational path and performance. Second, graduates are requested to answer another questionnaire on their early labor market experience after 1, 3 and 5 years from graduation. From our point of view, this means that it is possible to study the impact of parental background on several indicators of university performance - final grade and time needed to get a degree - but without controlling for the probability of obtaining a degree.

We study correlation between parental and children education. Hertz et al. (2007) take correlation coefficients as measures of standardized mobility and suggest that they have reduced in some countries, but increased in others, as a consequence of increasing access to education. Instead, the regression coefficient of parents' education as a predictor of schooling in the next generation fell substantially over 50 years. They interpret this finding as pointing to increasing “intergenerational grade mobility”.

Based on AlmaLaurea methodological notes, data relative to post-reform graduates refer to the so-called "pure graduates", meaning those graduates that have followed the same university track since their matriculation. In 2008, "Pure graduates" represented $89.5 \%$ of the 159,000 post-reform graduates (three-year first level degree, two-year second level degrees, five-year university degree) that have answered the AlmaLaurea questionnaire. 
Data are broken down by two main categories. First is the educational level and second is the social class of parents. Social classes are summarized in Table A1 in the Appendix ${ }^{5}$.

Some caveats are in order when looking at the data regarding university graduates, especially in the case of Italy. Due to the large gap between actual and curricular years necessary to attain a degree, considering only post-reform graduates might imply sample selection bias when attempting to assess the effect of the reform: in fact, the graduates included in the sample represent the elite of their cohort of registered students. The probability of success would dramatically reduce when considering also students who have still to complete their studies. Considering the high share of dropouts from Italian Universities, mentioned previously, this suggests that most probably the positive effect of parental background on university performance is dramatically underrated in the AlmaLaurea data. More information should be drawn in the future from merging AlmaLaurea data with university registry data to study the composition of dropouts by educational background.

A minor caveat refers to the fact that due to the proliferation of academic courses of study that each faculty has organized, some degrees are different from others within the same faculty in terms of skills and competencies acquired. This is for instance the case of the faculty of Law which awards a 5-year degree in Law (Laurea Magistrale in Giurisprudenza) that gives access, among others, to the liberal profession of barrister, but also a 3-year degree in Juridical Services that gives only access to some white collar jobs in the state sector. Medicine and Nursing are a similar example. To take into account this problem, AlmaLaurea data distinguishes Medicine and Dentistry, on the one hand, and Nursing, on the other. In the case of law faculties, the small number of graduates in Juridical Services suggests that the bias is minimal.

\section{The socio-economic background of AlmaLaurea graduates}

Having a glance at AlmaLaurea data relative to 2008 confirms the frame drawn by looking at Eurostat and OECD data and provides further food for thought. Figure 1 shows that in 2008 the graduates with at least one parent holding a university degree (25.6\%) more or less equal the share of graduates whose parents have less than compulsory education (27.8\%). The share of graduates whose parents are not graduates equals $72.2 \%$. This is quite a high percentage that should be understood with reference to the general increase in the educational level of the population. Despite

\footnotetext{
${ }^{5}$ For further methodological details regarding the databank and the definition of variables, see the AlmaLaurea webpage: http://www.almalaurea.it/universita/profilo/profilo2007/premessa/info-variabili.shtml.
} 
the " $3+2$ " reform this indicator has remained quite stable in the last years, only slightly shrinking with respect to the 2000 value (74\%) (Cammelli, 2004; AlmaLaurea, 2010).

\section{[Figure 1 about here]}

AlmaLaurea data adds further details regarding the apparent differences of social background of graduates by type of degree. In particular, the share of graduates whose parents are not graduates fluctuates dramatically from one degree to the other. To show this, Figure 2 reports the difference from the mean of the share of graduates by type of degree and educational level of parents. The Figure refers to graduates holding the first level degree (3-year program) and the single cycle degree (5-year program). All bars are ordered in decreasing order of difference from the mean of graduates whose parents hold both degrees. It means that, for instance, in Medicine and Dentistry there is the greatest positive difference from the mean share of graduates whose parents hold both a university degree. In other words, there are $18 \%$ more graduates $(27.5 \%)$ than average (9.5\%) in Medicine and Dentistry that have parents holding a university degree.

\section{[Figure 2 about here]}

The figure highlights strong polarization with respect to some groups of university degree. Let us consider first the most striking cases: comparing the five-year degree in Medicine and Dentistry and the three-year degree in Nursing, it is apparent that in the former case the share of graduates with at least one parent holding a university degree is much higher than average, whereas in the case of nursing the most numerous group includes graduates with parents holding compulsory education or below.

The group with a higher than average share of both parents holding a university degree includes Law, Architecture, Engineering, and, to a lesser extent, Arts, Scientific degrees and Chemical and Pharmaceutical. The group with a higher than average share of parents with a low educational level includes Education, Political and Social sciences, Economics and Statistics, and, to a lesser extent, Physical Education and Agriculture.

The figure confirms that the share of graduates whose parents hold both a degree is higher than average in the case of degrees that provide access to liberal professions. In turn, this confirms the greater economic value of intergenerational transfers among this group of graduates. It is understandable that the expected returns to education of an individual depends not only on the household financial wealth, but, in some cases, also on the job specific human capital or on a 
specific economic activity that the household is able to transfer to its offspring ${ }^{6}$. In fact, starting a liberal profession is much less costly for those who already enjoy a human capital that the previous generation has accumulated. A reform of liberal professions that would ease the access to all would be an important factor to stimulate educational mobility as well.

Looking at the social background of graduates by type of degree reported in Figure 3 conveys similar conclusions. The figure regards graduates of the first level (3-year program) and of the single cycle degree (5-year program). It shows the difference from the mean of the share of graduates by each type of degree and social class. The data is ordered in descending order of the gap in terms of graduates belonging to the bourgeoisie. Recall from Table A1 in the Appendix that the bourgeoisie includes also liberal professions.

The graduates with parents belonging to the bourgeoisie are greater than average among those attaining a degree in Medicine and Dentistry, Architecture, Law, and Chemistry or Pharmacy. This confirms the weight of intergenerational transfers among the entrepreneurial and professional social classes. Parents of graduates in Arts, Engineering, Geology and Biology and scientific degrees belong to the class of white collar workers. Instead, graduates in Agriculture, Economics and Statistics and Physical Education belong to the petty bourgeoisie. Last, parents of graduates in Education, Nursing and, to a lesser extent, Languages belong more frequently than average to the working class.

\section{[Figure 3 about here]}

The situation does not change if one looks at the socio-educational background of parents of graduates in second level degrees, including the two-year master program, reported in Figure 4. This should not surprise us considering the highest share of those who continue their studies after attaining the three-year diploma. Also in this case, the distributions are ordered by the gap from the mean in the share of graduates with parents belonging to the bourgeoisie.

\section{[Figure 4 about here]}

A lengthier study would require disaggregating the data by gender, considering the higher than average share of women among graduates (60\%) and the different gender composition of many types of degree. As Figure 5 shows, in fact, with few exceptions, such as Medicine and Dentistry, female graduates generally choose Education, Arts, Languages and Psychology. As previously shown, these types of degree are featured by the highest concentration of graduates with parents

\footnotetext{
${ }^{6}$ We gratefully acknowledge the remark of one of the referees who notes that to fully confirm this one should compare the type of degree held by parents and children.
} 
belonging to the lowest social class and educational background. Instead, the degrees belonging to the fields of Mathematics and Physics and Engineering are typically male dominated. In addition, these shares seem to be essentially constant from 2001.

\section{[Figure 5 about here]}

\section{Walk of life and university performance}

Another interesting link is that between socio-economic condition and university performance. Two indicators of performance have been used: the final grade and the delay in years to attain the degree. The latter indicator is particularly interesting, because in Italy there is a large average difference between actual and curricular years to attain a university degree. The evidence shows the existence of a strong impact of parents' educational level on offspring university performance under this respect. Figure 6 shows the negative relationship existing between length of the university path and education attainment of parents. In fact, the graduates who are offspring of parents with a high level of education tend to attain a degree much sooner than average ${ }^{7}$. This finding echoes that of several previous studies (see, among others, Cappellari, 2004; Checchi, Fiorio and Leonardi, 2008).

\section{[Figure 6 about here]}

Figure 7 confirms that the educational level of parents closely shapes also the distribution of grade point averages by a negative linear slope. As well-known in the literature (see Kreuter et al., 2010; and the references therein), the educational level of those young people who do not report their parents' educational level is, for obvious reasons, generally lower than average. The difference in grades amounts to only few decimals, though, from 25.7 out of 30 for graduates that do not declare the educational level of their parents to 26.3 for those who declare to have both parents with a university degree. The difference in grades is less striking than possibly expected for two main reasons: first is the strong heterogeneity of grades across degrees; second, and related to the previous point, is the fact that, in some faculties, grades tend to concentrate around the upper tail of the distribution. Nonetheless, these differences are important and cannot be neglected.

\section{[Figure 7 about here]}

Omitted calculations regarding the link between social class of origin and grade point average show no clear pattern. This finding is confirmed whatever the indicator of performance chosen.

\footnotetext{
${ }^{7}$ This finding would probably be less strong if one controls for the different (shorter) length of humanistic and professional degrees.
} 
When estimating the conditional effect of several socio-educational variables on university performance indicators in a multivariate context, the educational level of parents does not seem to directly affect performance in a statistical significant way. This finding is in contrast with the unconditional results presented until now. In other words, regression coefficients seem to be weaker than correlation coefficients.

In particular, the regression coefficient between educational attainment of parents and final grade when attaining a university degree of their offspring tends to weaken until becoming scarcely significant from a statistical point of view, when the estimates control for grade attained at secondary high school. In other words, the grade attained at secondary high school is a good predictor of performance at the university also because it proxies the educational background. This finding confirms that school track - lyceum versus professional and technical schools - and the performance there is the channel through which the intergenerational transfer happens.

Multivariate analysis confirms also the scant statistical significance of belonging to a certain social class on the university performance of graduates.

The next two tables report results of OLS estimates of the effect of socio-economic variables and type of secondary high school on final grade at high secondary school (Table 2) and at the university (Table 3). The estimates distinguish between graduates of pre-reform degrees, postreform 3-year degrees, post-reform 5-year degrees, post-reform 2-year degrees. This allows us comparing pre- and post-reform graduates.

\section{[Table 2 about here]}

The determinants of the final grade achieved at high secondary school presented in Table 2 include: type of diploma, gender, educational level and social class of parents. The baseline group includes women from professional schools, whose parents have a low education attainment and belong to the working class. The table clearly shows that, with respect to graduates whose parents have achieved less than high secondary school taken as baseline, the performance in terms of grades at the high school diploma is better for graduates that have parents with a higher educational level, whatever the university track followed. Coefficients are all highly significant from a statistical point of view and exhibit little differences between graduates of the pre- and post-reform degrees. Another interesting finding regards the impact of belonging to a given social class. In fact, taking as a baseline the group of graduates whose parents belong to the working class, the return in terms of grade at the diploma of high school worsen as soon as we move up the social ladder. This finding should be probably read together with what happens when dividing graduates by type of high school diploma achieved. In fact, with respect to graduates holding a professional diploma, taken as 
baseline, grades at the lyceum (which tend to belong to the highest social class) tend to be lower. Last, but not least, men tend to have lower grades than women.

Nevertheless, the clear impact of socio-economic conditions on the educational path tends to be less apparent when taking into consideration the performance of university graduates. The most likely reason is that, as several observers (see, among others, AlmaLaurea reports; Cappellari, 2004; Brunello and Checci, 2007) have noted, the impact of the socio-educational background on university performance tends to pass through school track.

To show this, Table 3 reports the same type of estimates presented in Table 3, but referred to the final grade achieved at the university. As earlier, estimates refer to both pre- and post-reform degrees. For each type of degree, two models are presented. Model 1 includes only socio-economic variables and variables related to the type of university course attended. Model 2 includes also other variables, such as the type of diploma of high school, the final grade achieved at high school and the cultural motivation in choosing a given type of degree. Based on the literature review of Section 2, the additional variables of Model 2 are expected to affect university performance. In fact, the underlying hypothesis of these estimates is that the impact of family background goes through the choice of secondary school track.

In Model 1, the impact of socio-economic variables, found also in the case of the grade achieved at the high school diploma, seems to be still present although to a lesser extent. Nonetheless, when adding other explanatory variables, in Model 2, the positive impact of the higher educational level and upper walk of life of parents dramatically shrinks: in some cases, the signs shift and the estimated coefficients become not statistically significant.

\section{[Table 3 about here]}

This suggests that the socio-economic conditions of graduates do not affect their university performance directly, but rather indirectly, namely through other variables included in model 2, variables that are all highly significant from a statistical point of view. In each type of degree, a professional diploma of high secondary school (in the baseline) tends to worsen the performance of graduates with respect to any other type of high secondary school diploma. Second, the type of university degree is also important: belonging to the group of degrees in Economics and Statistics, Law, Engineering, Political and Social Sciences, Mathematics and Physics and Biology and Chemistry, worsens the performance with respect to other types of degree taken as baseline. Belonging instead to the group of Education and Arts degree tends to improve it. Third, motivational factors are also important: grades tend to be higher when graduates have chosen their type of degree based on strong cultural motivation. 
These effects do not change much if one compares the performance of pre- and post-reform graduates. Nevertheless, the coefficients tend to be lower in absolute value and in terms of statistical significance in the case of specialist degrees, meaning 5-year degrees and 2-year graduate degrees.

The educational level and socio-economic background of parents affect other features of graduates performance that for shortness sake here we have just mentioned. Having parents that have attained only lower educational levels typically correlates with a tendency to work while studying at the university. This, in turn, tends to generate a longer length of the study path (from 1.49 years of extra-curricular years for every year of curricular years) and lower final grades at the degree.

In addition, graduates with this type of family background tend to attend less frequently the Erasmus program. Attendance of the Erasmus program reaches a share of $10.8 \%$ among graduates whose parents have both a university degree and only $4.1 \%$ among graduates whose parents hold lower than high secondary education attainment. Moreover, the latter have a lower propensity to continue their studies and a tendency to register later than the canonical age at the university.

On a more positive note, they tend on average to receive a higher number of scholarships with respect to other graduates. Nonetheless, apparently this is not sufficient to counterbalance all the disadvantages that young people with a poor socio-educational background experience in their educational career.

\section{Concluding remarks}

AlmaLaurea data allows us to elaborate a better-articulated answer than that based on Eurostat and OECD data regarding the issue of socio-educational mobility. First, the statistics relative to 2008 provide further detailed evidence on a result achieved in the last AlmaLaurea enquiries on the role of the socio-educational background of graduates: the 1999 reform of the university system has only marginally contributed to "democratize” access to tertiary education. In fact, AlmaLaurea data shows that during the last decade, the share of graduates whose parents have a poor walk of life has only slightly increased. The small improvement is due to the increased supply of tertiary education and goes against the positive expectations of graduation that students have shown at the outset of the reform process when the number of matriculations has dramatically increased (Bratti et al., 2008). 
This paper provides evidence supporting the view that the " $3+2$ " reform has been unable to change the "classist" nature of the tertiary educational system. The educational background and walk of life of students still play a decisive role in determining their success at the university. They affect not only the likelihood to achieve a degree, but also other indicators of performance, such as the type of university degree chosen, the length of studies and the final grade. In turn, these are all potentially important factors of success in early labor market experiences.

The paper has shown in fact that the share of graduates enrolled in the 3-year post-reform program whose parents have both attained a university degree is above average in the case of degrees that provide the qualification necessary to access liberal professions, namely Medicine and Dentistry, Law, Architecture, Pharmacy, Engineering. It is clear that, in liberal professions, the economic value of intergenerational transfers is particularly high.

Similar conclusions can be reached when looking at the intergenerational transfer of social status, which seems to further confirm the strong link between educational level and social class of origin.

Finally, it should be noted that the educational level and the social class of parents are accurate predictors of the length of university studies, which is much shorter in the case of graduates whose walk of life is upper than average, and also of the final grade. Econometric estimates confirm that, as a large literature has also noted, the influence of the socio-economic condition of the household of origin on graduates' university performance is indirect. Indeed, it goes through the choice of the type of high school and the performance there.

More than ten years after the Bologna declaration, this paper argues that Italy still presents a high degree of social immobility, greater not only than the majority of EU countries, but also the United States. Nevertheless, the direct cost of education is generally much higher in the EU and more so in the United States than in Italy. Then, this is evidence that the direct cost of tertiary education is neither the only nor the most important barrier to access high education for individuals coming from a poor walk of life. Apparently, there are other aspects of the educational system that affect its ability to supply equal opportunities to all. One important factor is the indirect cost of education, especially tertiary education, as measured in terms of foregone income that students undergo first to achieve a university degree and then to complete their extremely sluggish school-to-work transitions. Overall, young people should foresee an average of 7-8 years to achieve a degree and an average of 3 years to find a job. This paper has shown that in the case of individuals coming from a poor walk of life this length of time tends to further increase. 
In addition, it seems clear that the reform of the educational system has failed to reduce the direct and indirect cost of education. This is not only contrary to the aims of the Italian Constitution, in as much as it hinders access to education to the most talented young people belonging to the lowest socio-educational classes, but is also a factor of allocative inefficiency and of the lowest rate of technological innovation and growth in the long run. In turn, this contributes to generate a serious disadvantage for the country in the international competition in an ever more globalised world.

These conclusions raise a number of issues that are relevant to policy makers. Considering that the 2001 " $3+2$ " reform has not been able to reduce the cost of education and that such cost represents often an insuperable barrier especially for the lowest social classes beyond individual skills, what is there that can be done to grant equal access to the university? It is apparent that the expenditure in scholarships, equipment and university headquarters is still insufficient. A common feature of all recent university reforms is that they have been implemented with no additional cost for the state. It is therefore necessary first of all to revert this tendency and, secondly, to re-launch the spirit of the 2001 reform with interventions aimed at favoring a drastic reduction in the average length of university studies without reducing their quality level.

In addition, it would be urgent to remove the numerous factors that have reduced the effectiveness of the reform process. First is the reform of liberal professions, which has been announced several times, but never approved, and, second is the lack of recognition of the threeyear degree for seating public concourses, accessing liberal professions and the labor market in general. This explains why about $85 \%$ of those who obtain a 3-year degree continue their studies up to the 5th year. In addition, choosing the high road to development would require investing much more in the educational system to increase the quantity and quality of tertiary education. 


\section{Bibliographical references}

AlmaLaurea (ed., 2008), IX profilo dei laureati in Italia. La riforma allo specchio, Il Mulino, Bologna.

AlmaLaurea (ed., 2010), XI profilo dei laureati in Italia. Valutazione dei percorsi formativi nell’Università a dieci anni dalla Dichiarazione di Bologna, Il Mulino, Bologna.

Bjorklund, A. and K. Salvanes (2010) "Education and Family Background: Mechanisms and Policies”, in E. A Hanushek, S. Machin, L. Woessmann (eds.), Handbook of the Economics of Education, Vol. 3, North-Holland.

Black, S.E. and P.J. Devereux (2010), “Recent Developments in Intergenerational Mobility”, O. Ashenfelter and D. Card (eds.), Handbook of Labor Economics, Vol. 4B, Chapter 16, NorthHolland.

Blanden, J., e P. Gregg (2004) "Family income and educational attainment: a review of approaches and evidence for Britain”, Oxford Review of Economic Policy, 20(2): 245-263.

Bratti, M., D. Checchi and G. de Blasio (2008) "Does the expansion of higher education increase equality of educational opportunities? Evidence from Italy”, Labour 22 (Special Issue): 5388.

Brunello, G., D. Checchi (2007), "Does School Tracking Affect Equality of Opportunity? New International Evidence”, Economic Policy, 22(52): 781-861.

Brunello, G., S. Comi e C. Lucifora (1999), "Returns to Education in Italy: A Review of the Applied Literature”, in R. Asplund and P. Telhado Pereira (a cura di), Returns to Human Capital in Europe. A literature Review, ETLA, Helsinky.

Brunello, G., S. Comi e C. Lucifora (2000), "Returns to Education in Italy: A New Look at the Evidence”, IZA Discussion Paper, No. 130, March.

Cammelli, A. (2004), “Migliora l'occupazione, ma rallenta la capacità attrattiva del mercato del lavoro", in AlmaLaurea (a cura di), IV indagine AlmaLaurea sulla condizione occupazionale dei laureati, Il Mulino, Bologna (anche disponibile al sito: https://www.almalaurea.it/universita/occupazione/occupazione00/presentazione.shtml).

Cammelli, A. and G. Gasperoni (2008), "Più diversi che eguali. Origini sociali, retroterra formativo e riuscita negli studi dei laureate”, in A. Cammelli and G. Vittadini (eds.), Capitale umano: esiti dell'istruzione universitaria, Il Mulino, Bologna.

Cappellari, L. (2004) "The Effects of High School Choices on Academic Performance and Early Labour Market Outcomes," Royal Economic Society Annual Conference, Royal Economic Society.

Cappellari, L. and C. Lucifora (2009), “The Bologna Process and College Enrolment Decisions”, Labour Economics, 16(6): 638-647.

Checchi, D. (2003), "The Italian Educational System: Family Background and Social Stratification”, in ISAE (ed.), Monitoring Italy, ISAE, Rome.

Checchi, D. (2006), The Economics of Education. Human Capital, Family Background and Inequality. Cambridge University Press, Cambridge.

Checchi, L., C. V. Fiorio, M. Leonardi (2008), "Intergenerational Persistence in Educational Attainment in Italy”, IZA discussion paper, $\mathrm{N}^{\circ} 3622$.

Checchi, D., L. Flabbi (2007), "Intergenerational Mobility and Schooling Decisions in Germany and Italy: The Impact of Secondary School Track”, IZA discussion paper, n. 2876.

Checchi, D., A. Ichino and A. Rustichini (1999), "More Equalbut Less Mobile? Education Financing and Intergenerational Mobility in Italy and in the USA", Journal of Public Economics, 74(3): 351-393. 
Consorzio Interuniversitario AlmaLaurea (2008), IX profilo dei laureati italiani. La riforma allo specchio, Il Mulino, Bologna.

Dustmann, C. (2004), "Parental Background, Secondary School Track Choice, and Wages”, Oxford Economic Papers. 56 (2): 209-230.

Eurostat (2009a), “30\% of 25-34 Year-olds in the EU27 are Graduates from Higher Education”, Eurostat News Release, n. 58, 28 Aprile.

Eurostat (2009b), “Youth in Europe: A Statistical portrait”, Eurostat, Luxembourg.

Hertz, T., T. Jayasundera, P. Piraino, S. Selcuk, N. Smith, e A. Verashchagina (2007) "The Inheritance of Educational Inequality: International Comparisons and Fifty-Year Trends,” The B.E. Journal of Economic Analysis \& Policy: 7(2: Advances): Article 10.

Kreuter, F., S. Eckman, K. Maaz and R. Watermann (2010), "Children's Reports of Parents' Educational Level: Does it Matter Whom You Ask and What You Ask About?”, Survey Research Methods, 4(3): 127-138.

Lochner, L.J. (2008), "Intergenerational Transmission", in S. N. Durlauf and L. E. Blume (eds.), The New Palgrave Dictionary of Economics, $2^{\text {nd }}$ Edition. Palgrave Macmillan, 2008.The New Palgrave Dictionary of Economics Online. Palgrave Macmillan.

Mincer, J. (1958) “Investment in Human Capital and Personal Income Distribution” Journal of Political Economy, 66(4): 281-302.OECD (2009; and 2010), Education at a Glance, OECD, Paris.

OECD (various years), Education at a Glance, OECD, Paris.

O'Higgins, N., M. D'Amato, F.E. Caroleo e A. Barone (2007) "Gone for Good? Determinants of School Dropout in Southern Italy”, Giornale degli Economisti e Annali di Economia, 66(2): 207-246.

Pastore, F. (2009), “School-to-Work Transitions in Italy: A Steeplechase with No Winner?”, XXIV Conference of the Italian Association of Labour Economics, University of Sassari, September. 


\section{Appendix of Tables and Figures}

Table 1. Percentage of individuals with completed tertiary education by the educational level of their parents (2005)

\begin{tabular}{|c|c|c|c|c|c|c|}
\hline & \multicolumn{2}{|c|}{ Low* } & \multicolumn{2}{|c|}{ Medium* } & \multicolumn{2}{|c|}{ High* } \\
\hline & Age 25-64 & Age 25-34 & Age 25-64 & Age 25-34 & Age 25-64 & Age 25-34 \\
\hline EU25 & 16.5 & 22.9 & 31.7 & 30.3 & 62.5 & 60.9 \\
\hline Belgium & 21.4 & 26.2 & 50.2 & 51.2 & 78.2 & 82.3 \\
\hline Bulgaria & : & : & : & : & : & : \\
\hline Czech Republic & 4.4 & 2.5 & 11.4 & 10.1 & 50.9 & $48.6^{\mathrm{u}}$ \\
\hline Denmark & 19.0 & $20.3^{u}$ & 26.8 & 28.9 & 53.6 & $53.4^{\mathrm{u}}$ \\
\hline Germany & : & : & : & : & : & : \\
\hline Estonia & 18.8 & 4.6 & 30.6 & 23.7 & 54.0 & $48.0^{\mathrm{u}}$ \\
\hline Ireland & 20.6 & 37.0 & 54.9 & $60.0^{\mathrm{u}}$ & 76.7 & $77.0^{\mathrm{u}}$ \\
\hline Greece & 15.3 & 18.1 & 42.7 & $39.3^{\mathrm{u}}$ & 63.8 & $63.0^{4}$ \\
\hline Spain & 21.1 & 31.6 & 49.6 & 54.3 & 71.2 & 73.0 \\
\hline France $^{\star *}$ & 19.8 & 32.1 & 47.1 & $54.0^{\mathrm{u}}$ & 70.8 & 78.9 \\
\hline Italy & 7.7 & 9.1 & 32.6 & 28.8 & 60.7 & 60.2 \\
\hline Cyprus & 18.7 & 25.6 & 52.0 & 51.6 & 79.4 & $79.2^{\mathrm{u}}$ \\
\hline Latvia & 9.5 & 8.5 & 23.0 & 19.0 & 52.6 & $44.3^{\mathrm{u}}$ \\
\hline Lithuania & 15.3 & 15.3 & 29.9 & 29.0 & 62.2 & $65.0^{\mathrm{u}}$ \\
\hline Luxemburg & 11.1 & 14.3 & 31.2 & 39.0 & 78.0 & 81.2 \\
\hline Hungary & 6.1 & 2.9 & 18.7 & 16.9 & 57.6 & 55.0 \\
\hline Malta & 6.7 & 10.0 & $27.9^{u}$ & $36.1^{\mathrm{u}}$ & $43.9^{\mathrm{u}}$ & : \\
\hline The Netherland & 22.9 & 30.2 & 41.4 & $41.8^{\mathrm{u}}$ & 68.0 & 67.8 \\
\hline Austria & 12.7 & 13.0 & 25.3 & 26.2 & $54.4^{\mathrm{u}}$ & $53.0^{\mathrm{u}}$ \\
\hline Poland & 6.2 & 8.5 & 22.1 & 25.1 & 66.6 & 73.6 \\
\hline Portugal & 10.2 & 15.4 & $53.7^{\mathrm{u}}$ & $:$ & $61.4^{\mathrm{u}}$ & $60.2^{\mathrm{u}}$ \\
\hline Romania & : & : & $:$ & $:$ & $:$ & : \\
\hline Slovenia & 4.4 & 6.5 & 19.3 & 23.4 & $42.4^{\mathrm{u}}$ & $33.1^{\mathrm{u}}$ \\
\hline Slovak Republic & 7.5 & 4.2 & 18.3 & 16.0 & 51.2 & $45.4^{\mathrm{u}}$ \\
\hline Finland & 25.6 & 25.6 & 39.7 & 38.2 & 57.9 & 52.1 \\
\hline Sweden & 22.6 & 26.0 & 45.1 & $44.4^{\mathrm{u}}$ & 59.1 & $58.7^{\mathrm{u}}$ \\
\hline United Kingdom & 26.9 & 38.0 & 42.5 & 50.2 & 67.3 & 73.3 \\
\hline Island & 12.5 & $14.1^{\mathrm{u}}$ & 27.4 & $29.3^{\mathrm{u}}$ & $52.5^{\mathrm{u}}$ & $50.6^{\mathrm{u}}$ \\
\hline Norway & 16.3 & $21.9^{\mathrm{u}}$ & 30.8 & 30.6 & 54.9 & 56.0 \\
\hline
\end{tabular}

* Low (ISCED 0-2), medium (ISCED 3-4) and high (ISCED 5-6)

** Provisional data

: Data not available

$\mathrm{u}$ due to the small sample size data should be used with caveat.

Source: EU-SILC. 
Table 2. Socio-educational determinants of final grade at secondary high school (2008)

\begin{tabular}{|c|c|c|c|c|c|c|c|c|}
\hline & \multicolumn{2}{|c|}{$\begin{array}{l}\text { Pre-reform } \\
\text { degrees }\end{array}$} & \multicolumn{2}{|c|}{$\begin{array}{l}\text { Post-reform 3-year } \\
\text { degrees }\end{array}$} & \multicolumn{2}{|c|}{$\begin{array}{l}\text { Post-reform 5-year } \\
\text { degrees }\end{array}$} & \multicolumn{2}{|c|}{$\begin{array}{l}\text { Post-reform 2-year } \\
\text { degrees }\end{array}$} \\
\hline & B & $\begin{array}{r}\text { Standar } \\
\mathrm{d} \\
\text { error }\end{array}$ & B & Standard error & B & $\begin{array}{r}\text { Standard } \\
\text { error }\end{array}$ & B & Standard error \\
\hline Constat & $\begin{array}{r}81,8^{* *} \\
*\end{array}$ & 0,56 & $83,5^{\star \star \star}$ & 0,25 & $94,1^{* \star \star}$ & 1,47 & $86,2^{* * *}$ & 0,61 \\
\hline \multicolumn{9}{|l|}{ DIPLOMA of secondary high school: } \\
\hline Lyceum, classical studies & $-2,9^{\star \star \star}$ & 0,58 & 0,0 & 0,28 & $-2,9^{\star \star}$ & 1,47 & 0,7 & 0,62 \\
\hline Lyceum, linguistic studies & $-1,6^{\star *}$ & 0,68 & $1,8^{\star \star \star}$ & 0,29 & $-5,3^{* \star *}$ & 1,66 & $2,2^{\star \star *}$ & 0,67 \\
\hline Lyceum, scientific studies & $-3,4^{\star \star \star}$ & 0,57 & $-0,3$ & 0,26 & $-4,5^{\star \star \star}$ & 1,45 & 0,8 & 0,61 \\
\hline Lyceum, psico-socio-pedagogic, education or arts & $-2,4^{\star \star \star}$ & 0,61 & $-0,2$ & 0,28 & $-2,0$ & 1,63 & 1,0 & 0,66 \\
\hline Technical school & $-0,4$ & 0,57 & $0,6^{\star \star \star}$ & 0,26 & $-5,9^{* \star \star}$ & 1,50 & $2,1^{\star \star \star}$ & 0,61 \\
\hline Professional school (baseline) & & & & & & & 0,0 & \\
\hline \multicolumn{9}{|l|}{ Gender, of which: } \\
\hline Men & $-2,1^{\star \star \star}$ & 0,18 & $-4,0$ *** & 0,09 & $-4,1^{1 * *}$ & 0,29 & $-2,4^{\star \star *}$ & 0,14 \\
\hline \multicolumn{9}{|l|}{ Women (baseline) } \\
\hline \multicolumn{9}{|l|}{ Educational attainment of parents } \\
\hline Both parents got a university degree & $4,2^{* \star *}$ & 0,39 & $4,8^{\star * *}$ & 0,20 & $4,0^{\star \star \star}$ & 0,55 & $3,9^{\star \star *}$ & 0,29 \\
\hline Only one parent got a university degree & $1,7^{\star \star \star}$ & 0,31 & $2,9^{\star * *}$ & 0,16 & $2,6^{\star \star \star}$ & 0,52 & $2,1^{\star \star *}$ & 0,25 \\
\hline At least one parent got high secondary school diploma & $1,1^{\star \star \star}$ & 0,22 & $1,7^{\star \star *}$ & 0,11 & $1,7^{\star \star \star}$ & 0,44 & $1,0^{\star \star *}$ & 0,19 \\
\hline \multicolumn{9}{|l|}{ Lower educational attainment (baseline) } \\
\hline \multicolumn{9}{|l|}{ Social class } \\
\hline Bourgeoisie / top management & $-2,7^{\star \star \star}$ & 0,40 & $-2,0^{* * *}$ & 0,20 & $-1,9^{\star \star \star}$ & 0,60 & $-2,4^{\star \star \star}$ & 0,30 \\
\hline Bourgeoisie / professionals / entrepreneurs & $-2,5^{\star \star \star}$ & 0,32 & $-2,3^{* * *}$ & 0,15 & $-2,4^{\star \star \star}$ & 0,52 & $-2,7 * \star *$ & 0,24 \\
\hline $\begin{array}{l}\text { Employees with coordination tasks / middle executive } \\
\text { managers }\end{array}$ & $-0,9^{\star \star}$ & 0,35 & $-0,8^{* \star \star}$ & 0,17 & $-0,5$ & 0,58 & $-0,6^{* *}$ & 0,26 \\
\hline Clerical staff, teachers & $-0,3$ & 0,26 & $-0,7^{7 * *}$ & 0,13 & $-0,2$ & 0,50 & $-0,4^{*}$ & 0,22 \\
\hline Petty bourgeoisie & $-0,9^{\star \star \star}$ & 0,24 & $-0,8^{\star \star \star}$ & 0,13 & $-1,2^{\star \star \star}$ & 0,50 & $-0,9^{* \star *}$ & 0,21 \\
\hline \multicolumn{9}{|l|}{ Working class (baseline) } \\
\hline Number of observations & 20139 & & 96105 & & 8962 & & 35,616 & \\
\hline Adjusted $\mathrm{R}^{2}$ & 0.02 & & 0.03 & & 0.05 & & 0.02 & \\
\hline
\end{tabular}

Note: OLS regressions. Dependent variable is the grade at the high secondary school diploma. Not-standardised coefficients. ${ }^{*}, * *, * \star *$ denote a significance level of 10,5 and $1 \%$ respectively.

Source: AlmaLaurea. 
Table 3. Determinants of university grade (2008)

\begin{tabular}{|c|c|c|c|c|c|c|c|c|c|c|c|c|c|c|c|c|}
\hline & \multicolumn{4}{|c|}{ Pre-reform degrees } & \multicolumn{4}{|c|}{$\begin{array}{c}\text { Post-reform 3-year } \\
\text { degrees }\end{array}$} & \multicolumn{4}{|c|}{$\begin{array}{l}\text { Post-reform 5-year } \\
\text { degrees }\end{array}$} & \multicolumn{4}{|c|}{$\begin{array}{c}\text { Post-reform 2-year } \\
\text { degrees }\end{array}$} \\
\hline & \multicolumn{2}{|c|}{ Model 1} & \multicolumn{2}{|c|}{ Model 2} & \multicolumn{2}{|c|}{ Model 1} & \multicolumn{2}{|c|}{ Model 2} & \multicolumn{2}{|c|}{ Model 1} & \multicolumn{2}{|c|}{ Model 2} & \multicolumn{2}{|c|}{ Model 1} & \multicolumn{2}{|c|}{ Model 2} \\
\hline & $\mathrm{B}$ & $\begin{array}{l}\text { Standard } \\
\text { error }\end{array}$ & $\mathrm{B}$ & \begin{tabular}{|l|} 
Stan \\
dard \\
error \\
\end{tabular} & $\mathrm{B}$ & $\begin{array}{l}\text { Stan } \\
\text { dard } \\
\text { error }\end{array}$ & $B$ & \begin{tabular}{|l|} 
Stan \\
dard \\
error
\end{tabular} & $B$ & \begin{tabular}{|l|} 
Stan \\
dard \\
error \\
\end{tabular} & $\mathrm{B}$ & $\begin{array}{l}\text { Stan } \\
\text { dard } \\
\text { error }\end{array}$ & $\mathrm{B}$ & $\begin{array}{l}\text { Stan } \\
\text { dard } \\
\text { error }\end{array}$ & B & \begin{tabular}{|l|} 
Stan \\
dard \\
error \\
\end{tabular} \\
\hline Constant & 103,5 & 0,15 & $\begin{array}{ll}78,3^{* \star} \\
*\end{array}$ & 0,49 & $\begin{array}{l}102,8^{\star \star} \\
*\end{array}$ & 0,08 & \begin{tabular}{|l|l|}
$74,3^{* \star}$ \\
$*$
\end{tabular} & 0,22 & & & $\begin{array}{l}81,7^{\star \star} \\
*\end{array}$ & 0,94 & $\begin{array}{l}109,6^{* \star} \\
*\end{array}$ & 0,09 & \begin{tabular}{|l|}
$93,9^{* \star}$ \\
$\star$
\end{tabular} & 0,33 \\
\hline \multicolumn{17}{|l|}{ Type of degree } \\
\hline Economics and Statistics & $5,4^{\star \star \star}$ & 0,19 & $\overline{5}_{5,5^{\star \star \star}}$ & 0,18 & $-4,4^{\star \star \star}$ & 0,09 & $4,4^{\star \star \star}$ & 0,08 & $\begin{array}{l}3,7^{* \star} \\
\star\end{array}$ & 0,19 & & & $-1,0^{\star \star \star}$ & 0,09 & $\begin{array}{l}- \\
1,1^{\star \star \star} \\
\end{array}$ & 0,09 \\
\hline Law & $8,1^{\star \star \star}$ & 0,16 & $8,5^{\star \star \star}$ & 0,15 & $-6,3^{* \star *}$ & 0,14 & $6,4^{* \star *}$ & 0,12 & & & $2,6^{* \star *}$ & 0,17 & $-2,1^{\star \star \star}$ & 0,12 & $2,7^{\star \star \star}$ & 0,11 \\
\hline Engineering & $3,8^{\star \star \star}$ & 0,19 & $6,0^{\star \star \star *}$ & 0,18 & $-3,0^{* * *}$ & 0,10 & $5,6^{* \star *}$ & 0,09 & & & & & $-1,2^{\star \star \star}$ & 0,10 & $2,7^{\star \star \star}$ & 0,09 \\
\hline Education and Arts & $3,4^{\star \star *}$ & 0,17 & $3,8^{\star \star \star}$ & 0,16 & $3,2^{\star \star \star}$ & 0,09 & $3,8^{\star \star \star *}$ & 0,08 & & & & & $1,7^{\star \star \star}$ & 0,11 & $1,5^{\star \star \star}$ & 0,10 \\
\hline Political and Social Sciences & $-3^{\star \star *}$ & 0,19 & $3,0^{\star \star \star *}$ & 0,18 & $-1,9 * \star \star$ & 0,08 & $1,0^{* \star \star}$ & 0,07 & $\begin{array}{l}5,2^{\star \star} \\
* \\
\end{array}$ & 0,19 & & & $-0,2^{\star \star}$ & 0,10 & $-0,2^{\star \star}$ & 0,09 \\
\hline Mathematics and Physics, Chemistry, Biology & $3,9^{\star \star \star}$ & 0,25 & $4,9^{\star \star \star}$ & 0,23 & 0,1 & 0,13 & $1,6^{\star \star \star}$ & 0,12 & & & $3,8^{\star \star *}$ & 0,17 & $0,9^{\star \star \star}$ & 0,15 & $-0,2^{*}$ & 0,14 \\
\hline Medicine and Dentistry & & & & & $1,2^{\star \star \star}$ & 0,10 & $3,4^{\star \star \star}$ & 0,09 & & & & & 0,2 & 0,28 & $2,0^{\star \star \star}$ & 0,27 \\
\hline \multicolumn{17}{|l|}{ Others (baseline) } \\
\hline \multicolumn{17}{|l|}{ Gender } \\
\hline Men & $1,8^{\star \star \star}$ & 0,11 & $\overline{0}, 7^{\star \star \star}$ & 0,11 & $-2,2^{* \star *}$ & 0,06 & - & 0,05 & $\begin{array}{l}1,5^{\star \star} \\
*\end{array}$ & 0,15 & $-0,2$ & 0,14 & $-1,1^{\star \star \star}$ & 0,06 & $-\overline{3} 3^{\star \star \star}$ & 0,06 \\
\hline Women (baseline) & & & 0,0 & & & & & & & & & & & & & \\
\hline \multicolumn{17}{|l|}{ Educational attainment of parents } \\
\hline Both parents got a university degree & $1,5^{\star \star \star}$ & 0,24 & $-0,4$ & 0,23 & $2,6^{\star \star \star}$ & 0,12 & $0,3^{\star \star \star}$ & 0,11 & $\begin{array}{l}1,6^{\star \star} \\
{ }^{\star 2} \\
\end{array}$ & 0,29 & 0,3 & 0,27 & $1,2^{\star \star \star}$ & 0,12 & 0,1 & 0,12 \\
\hline Only one parent got a university degree & $0,6^{\star \star \star}$ & 0,19 & $0,5^{\star \star *}$ & 0,18 & $1,4^{\star \star \star}$ & 0,09 & 0,0 & 0,08 & $\begin{array}{l}1,0^{* \star} \\
\star\end{array}$ & 0,28 & 0,0 & 0,25 & $0,5^{\star \star *}$ & 0,11 & $-0,1$ & 0,10 \\
\hline At least one parent got high secondary school diploma & $0,3^{\star \star}$ & 0,13 & $0,3^{\star * \star}$ & 0,12 & $0,6^{\star * *}$ & 0,07 & $0,2^{\star \star *}$ & 0,06 & $0,5^{\star *}$ & 0,24 & $-0,1$ & 0,21 & $0,2^{\star \star \star}$ & 0,08 & $-0,1$ & 0,08 \\
\hline Lower educational attainment (baseline) & & & & & & & & & & & & & & & 0,0 & \\
\hline \multicolumn{17}{|l|}{ Social class } \\
\hline Bourgeoisie / top management & $-0,2$ & 0,25 & 0,2 & 0,23 & $-0,5^{\star \star \star}$ & 0,12 & $-0,3^{\star \star}$ & 0,11 & $-0,2$ & 0,33 & 0,2 & 0,29 & $-0,4^{\star \star \star}$ & 0,13 & $-0,2$ & 0,12 \\
\hline Bourgeoisie / professionals / entrepreneurs & $\bar{j}_{0,6^{\star \star \star}}$ & 0,20 & $-0,1$ & 0,18 & $-1,0^{\star \star \star}$ & 0,09 & - & 0,08 & \begin{tabular}{|l|l}
$0,8^{\star *}$ \\
$*$ \\
\end{tabular} & 0,28 & $-0,2$ & 0,25 & $-0,5^{\star \star \star}$ & 0,11 & $-0,2^{\star \star}$ & 0,10 \\
\hline Employees with coordination tasks / middle executive managers & 0,3 & 0,22 & 0,3 & 0,20 & $-0,2^{\star}$ & 0,10 & $-0,1$ & 0,09 & $-0,2$ & 0,32 & $-0,2$ & 0,28 & 0,0 & 0,11 & 0,0 & 0,11 \\
\hline Clerical staff, teachers & 0,0 & 0,17 & 0,0 & 0,15 & $-0,2^{\star}$ & 0,08 & $-0,1^{\star}$ & 0,07 & $-0,4$ & 0,27 & $-0,4$ & 0,24 & 0,0 & 0,10 & $-0,1$ & 0,09 \\
\hline Petty bourgeoisie & $-0,1$ & 0,15 & 0,1 & 0,14 & $-0,3^{\star \star \star}$ & 0,08 & 0,0 & 0,07 & $-0,5^{*}$ & 0,27 & $-0,1$ & 0,24 & $-0,2^{*}$ & 0,09 & 0,0 & 0,09 \\
\hline \multicolumn{17}{|l|}{ Working class (baseline) } \\
\hline \multicolumn{17}{|l|}{ High secondary school diploma } \\
\hline Lyceum, classical studies & & & $5,8^{\star * \star}$ & 0,34 & & & $5,0^{\star \star \star *}$ & 0,15 & & & $4,1^{\star \star \star}$ & 0,71 & & & $2,7^{\star \star \star}$ & 0,26 \\
\hline Lyceum, linguistic studies & & & $4,4^{\star \star \star}$ & 0,39 & & & $3,6^{\star \star \star}$ & 0,16 & & & $2,5^{\star \star \star}$ & 0,80 & & & $1,7^{\star \star \star}$ & 0,27 \\
\hline Lyceum, scientific studies & & & $5,4^{\star \star \star}$ & 0,33 & & & $4,9^{\star \star \star}$ & 0,14 & & & $3,8^{\star \star \star *}$ & 0,70 & & & $2,5^{\star \star \star}$ & 0,25 \\
\hline Lyceum, psico-socio-pedagogic, education or arts & & & $2,9^{* \star *}$ & 0,35 & & & $2,0^{\star \star \star}$ & 0,15 & & & $1,5^{*}$ & 0,79 & & & $1,0^{\star \star \star}$ & 0,27 \\
\hline Technical school & & & $3,1^{\star \star \star}$ & 0,33 & & & $2,3^{\star \star \star}$ & 0,14 & & & $2,1^{\star \star *}$ & 0,73 & & & $1,2^{\star \star \star}$ & 0,25 \\
\hline \multicolumn{17}{|l|}{ Professional school (baseline) } \\
\hline Grade at the high secondary school diploma & & & $0,3^{\star \star \star *}$ & 0,00 & & & $0,3^{\star \star \star}$ & 0,00 & & & $0,3^{\star \star \star}$ & 0,01 & & & $0,2^{\star \star \star}$ & 0,00 \\
\hline Cultural motivation in choosing the type of university degree & & & & & & & & & & & & & & & & \\
\hline Very important & & & $1,4^{\star \star \star}$ & 0,14 & & & $1,7^{\star \star \star}$ & 0,06 & & & $1,4^{\star \star \star}$ & 0,19 & & & $1,0^{\star \star \star}$ & 0,06 \\
\hline Not much important & & & & & & & & & & & & & & & & \\
\hline Number of observations & 20141 & & 19655 & & 96110 & & 93885 & & 8962 & & 8553 & & 35618 & & 34913 & \\
\hline Adjusted $\mathrm{R}^{2}$ & 0.23 & & 0.36 & & 0.14 & & 0.32 & & 0.10 & & 0.34 & & 0.06 & & 0.18 & \\
\hline
\end{tabular}

Note: dependent variable is the final grade at the university degree. OLS regressions. Not-standardised coefficients. ${ }^{*}, * *$, , ${ }^{\star \star}$ denote a significance level of 10,5 and $1 \%$ respectively.

Source: AlmaLaurea. 


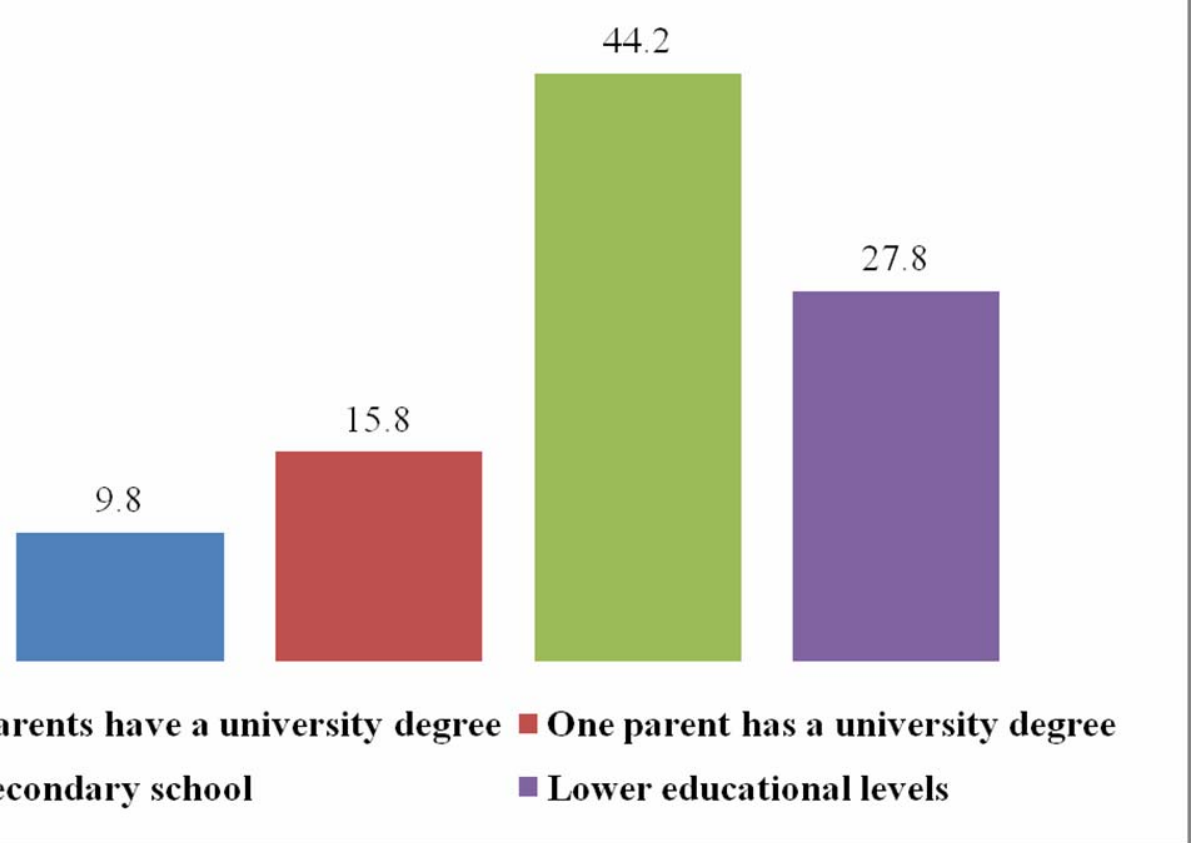

Note: All graduates in 2008.

Source: own elaboration on AlmaLaurea data.

Figure 2. Graduates of $\mathbf{1}^{\text {st }}$ level and single cycle degrees by educational level of parents and type of degree

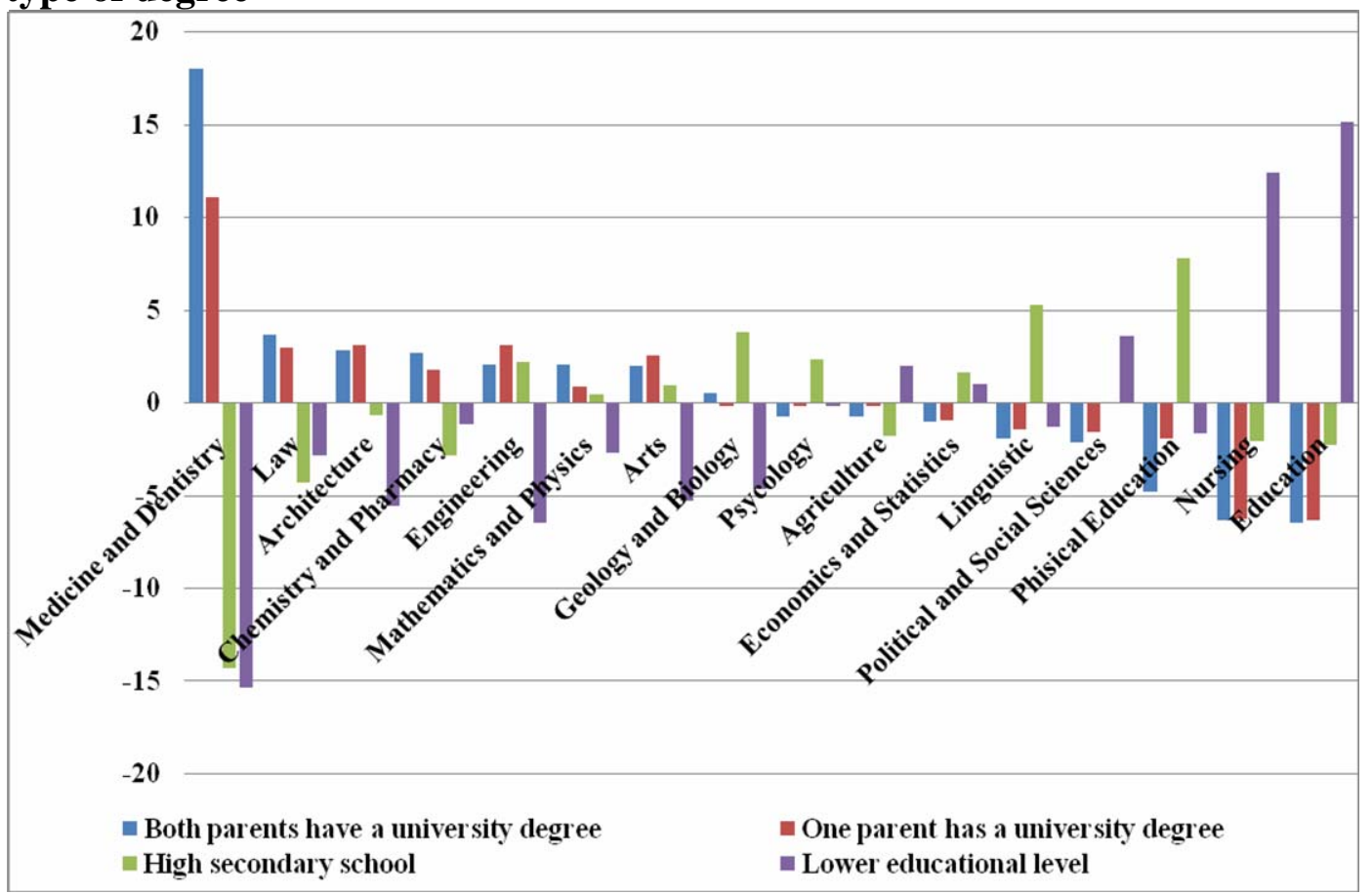

Note: Graduates of 3-year programmes (180 university credits) and so-called laurea specialistica a ciclo unico (5- or 6year single programme, providing 300 or 360 university credits) in 2008. LSCU degrees are: Medicine and Dentistry; Pharmacy, Architecture, Engineering and, from 2005, Law. Each bar measures the difference from the group mean share. Bars are ordered in descending order ot the difference share from the mean of graduates whose parents have both a degree.

Source: own elaboration on AlmaLaurea data. 
Figure 3. Graduates of 1st level and single cycle degrees by social class and type of degree

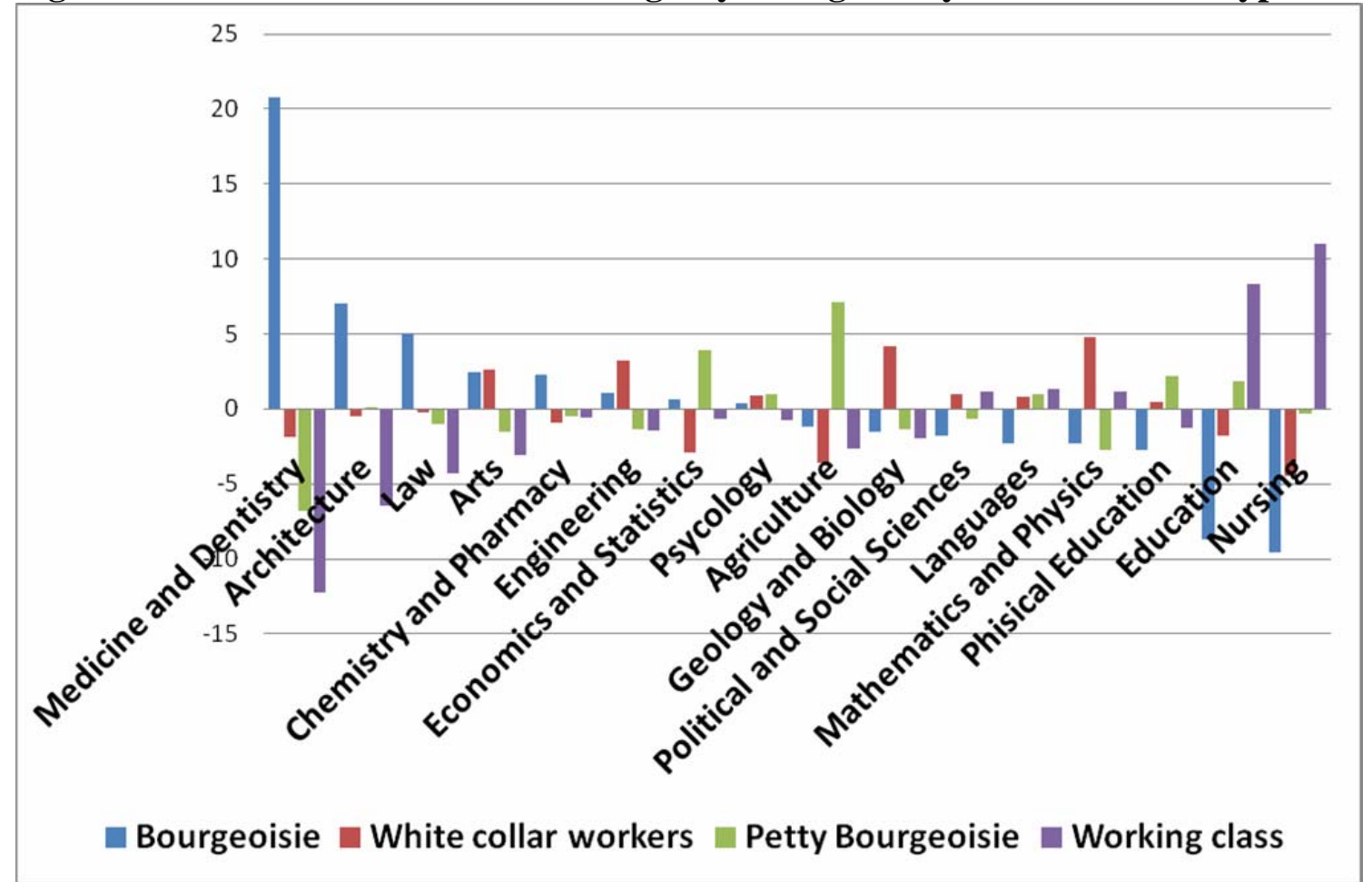

Note: See the note to Figure 2. Bars are here ordered in descending order ot the difference share from the mean of graduates whose parents belong to the bourgeoisie.

Source: own elaboration on AlmaLaurea data.

Figure 4. Graduates in laurea specialistica by social class and type of degree

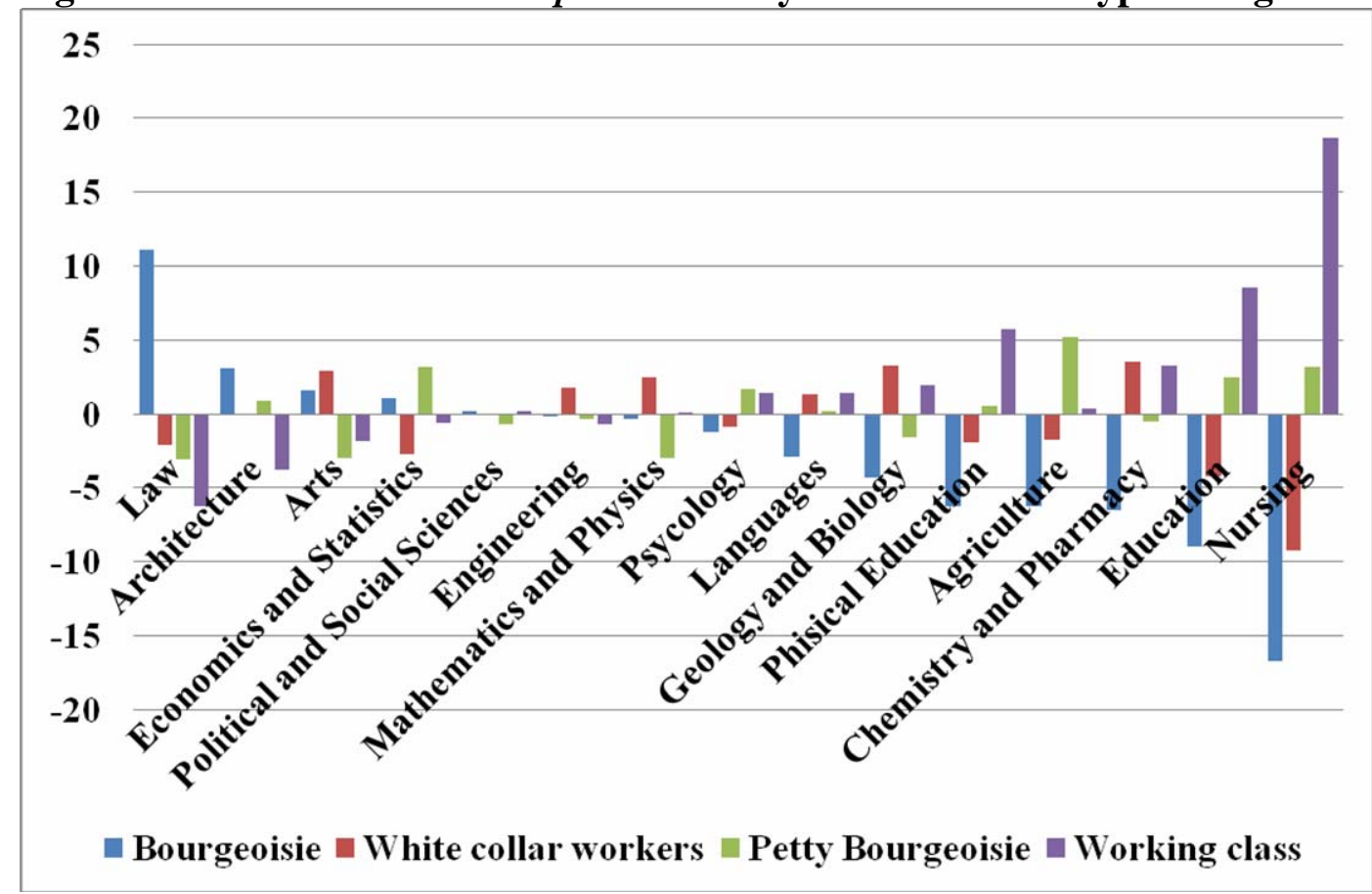

Note: Graduates of 2-year programmes in 2008 (master type). It includes also graduates in Law registered before 2005 in the " $3+2$ " program. Each bar measures the difference from the group mean share. Bars are ordered in descending order ot the difference share from the mean of graduates whose parents belong to the bourgeoisie.

Source: own elaboration on AlmaLaurea data. 
Figure 5. Graduates by gender

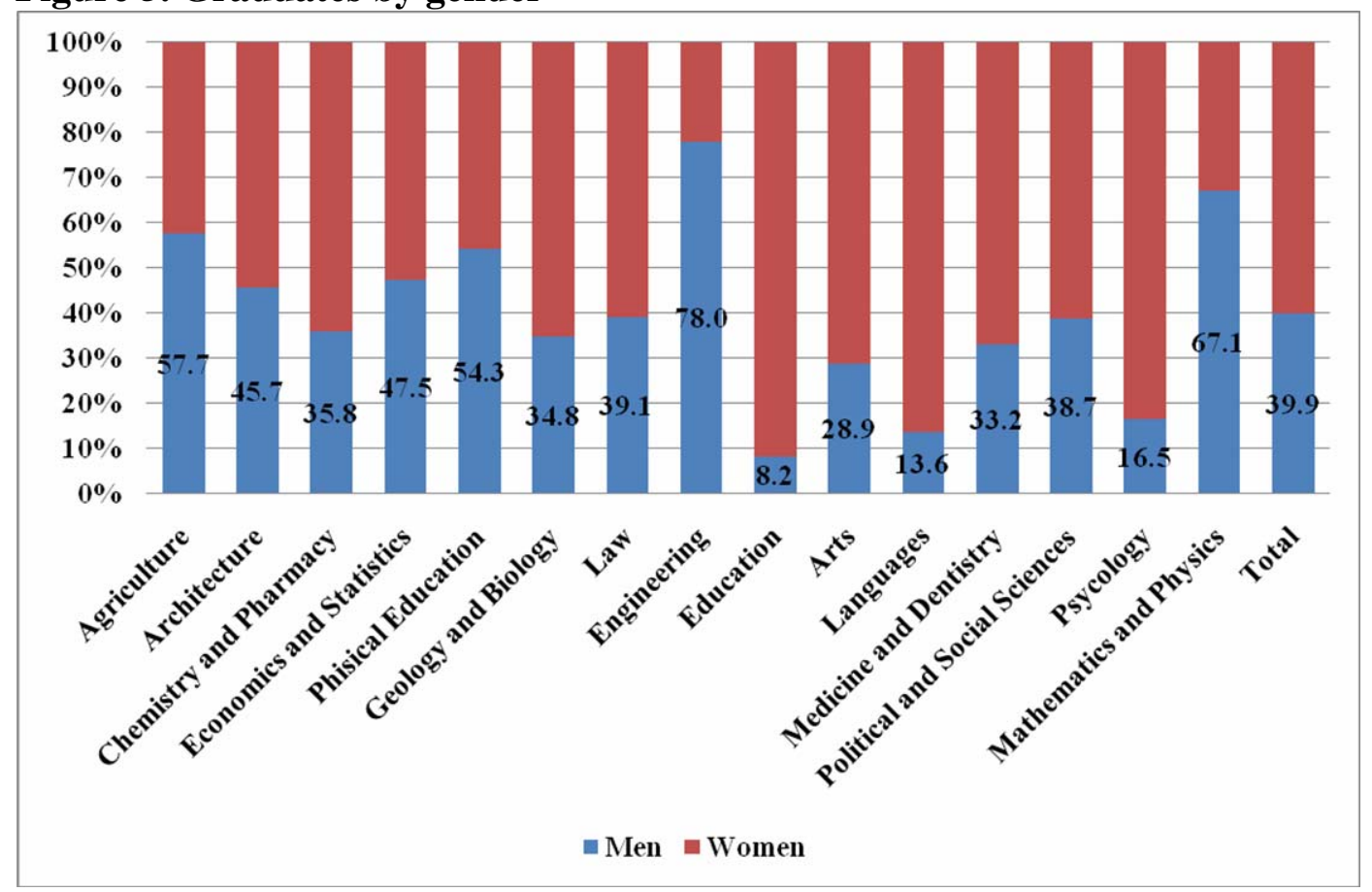

Note: All graduates in 2008.

Source: own elaboration on AlmaLaurea data.

Figure 6. Graduates by years of study and educational level of parents

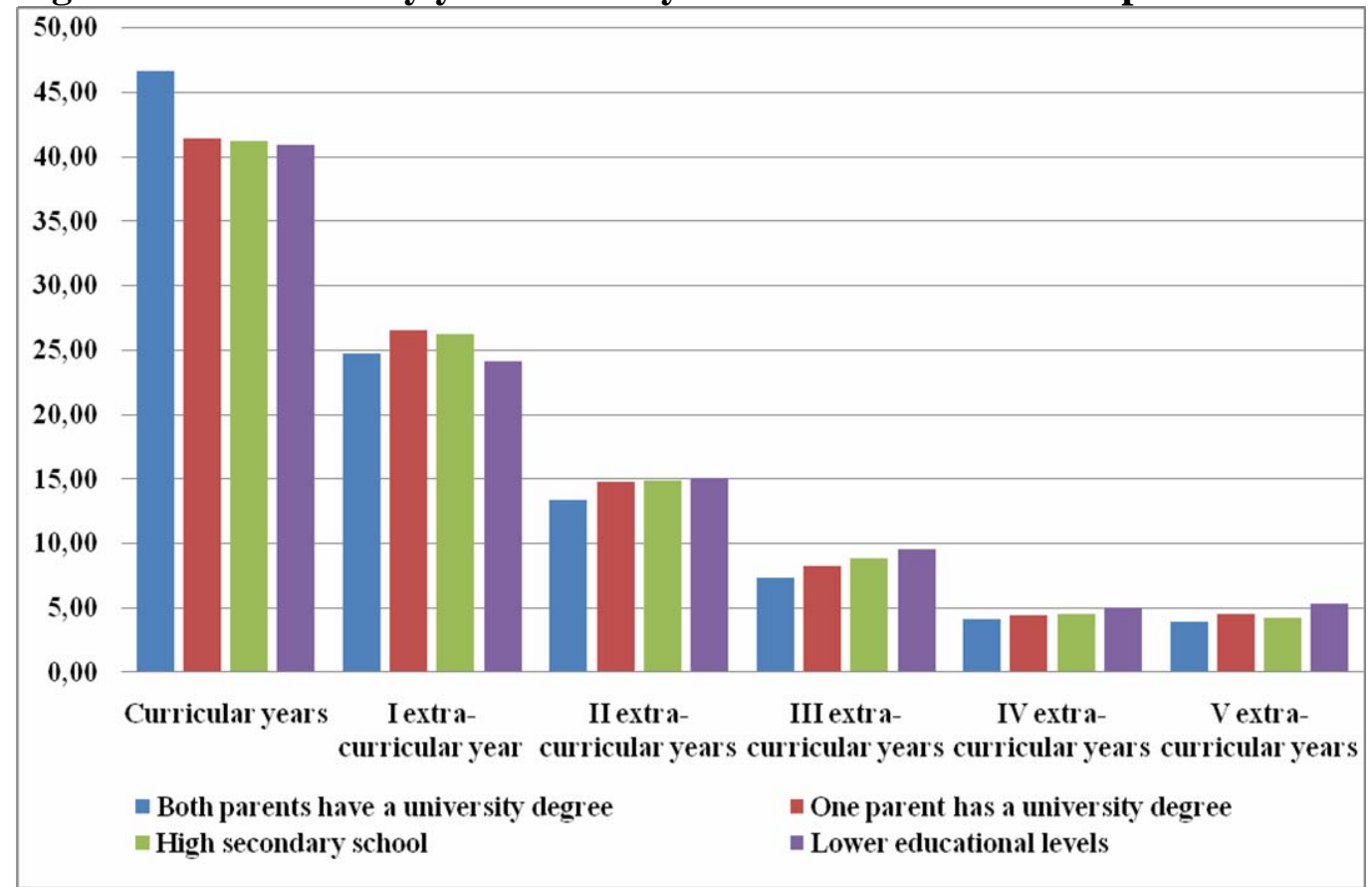

Note: The figure refers to graduates of 3-year programmes (180 university credits) and so-called laurea specialistica a ciclo unico (5- or 6-year single programme, providing 300 or 360 university credits) in 2008. LSCU degrees are: Medicine and Dentistry; Pharmacy, Architecture, Engineering and, from 2005, Law.

Source: own elaboration on AlmaLaurea data. 
Figure 7. Grade point average of graduates by educational attainment of parents

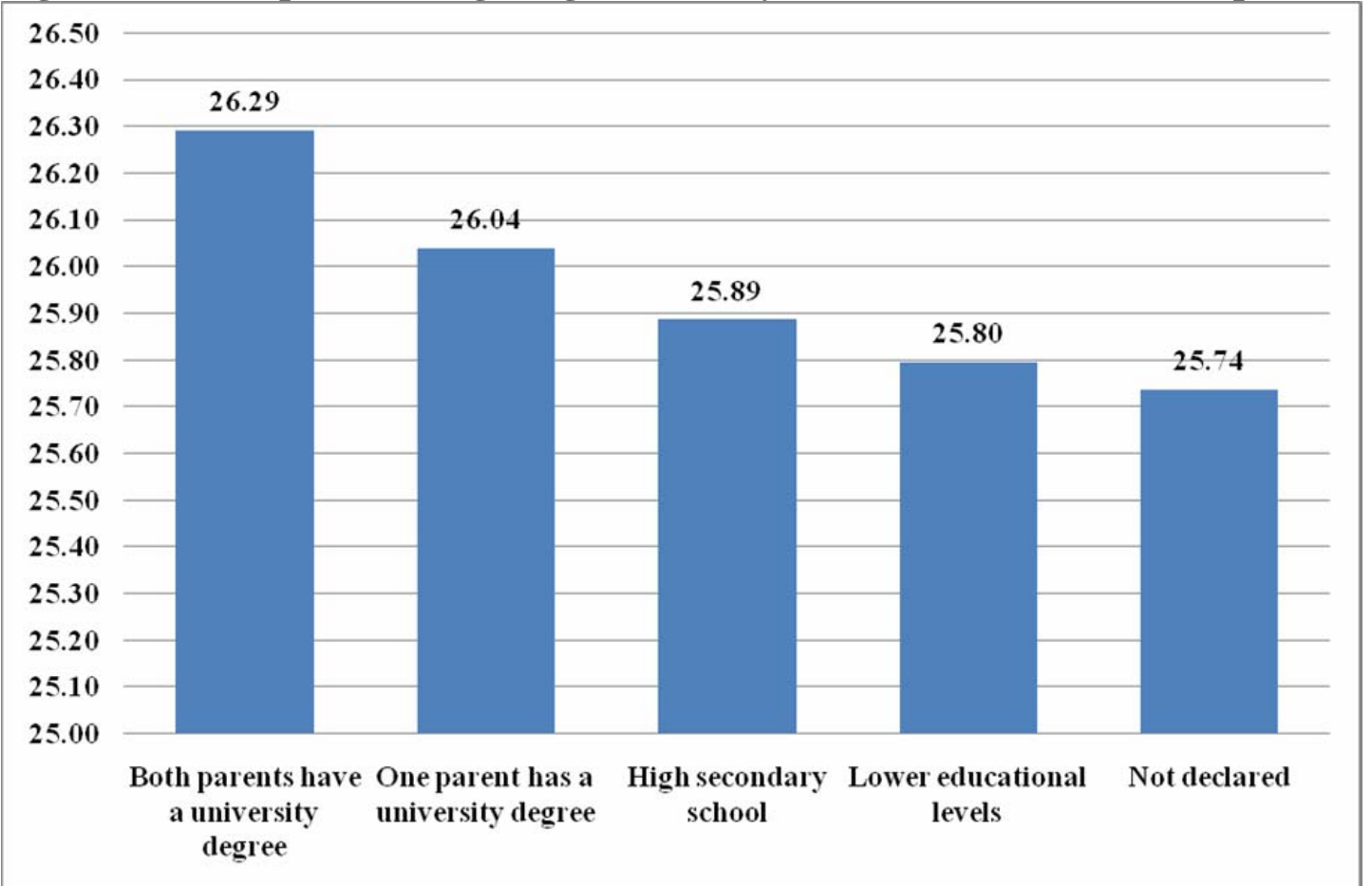

Note: The figure refers to graduates of 3-year programmes (180 university credits) and so-called laurea specialistica a ciclo unico (5- or 6-year single programme, providing 300 or 360 university credits) in 2008. LSCU degrees are: Medicine and Dentistry; Pharmacy, Architecture, Engineering and, from 2005, Law. Grades are in thirtieths.

Source: own elaboration on AlmaLaurea data. 
Table A1. Definition of social classes in AlmaLaurea

\begin{tabular}{|c|c|}
\hline Last position on the job & Socio-economic class \\
\hline $\begin{array}{ll}\text { - } & \text { professionals } \\
\text { - } & \text { managers } \\
\text { - } & \text { entrepreneurs with more than } 15 \text { employees }\end{array}$ & Bourgeoisie \\
\hline $\begin{array}{l}\text { - } \quad \text { employees with coordination tasks } \\
\text { - } \quad \text { middle executive managers } \\
\text { - } \quad \text { clerical staff }\end{array}$ & White collar workers \\
\hline $\begin{array}{ll}\text { - } & \text { self-employed } \\
\text { - } & \text { Family co-worker } \\
\text { - } & \text { members of cooperatives } \\
\text { - } & \text { entrepreneurs with less than } 15 \text { employees }\end{array}$ & Petty bourgeoisie \\
\hline $\begin{array}{l}\text { - } \quad \text { manual worker, wage employee and similar } \\
\text { clerk }\end{array}$ & Working class \\
\hline
\end{tabular}

